«Системні технології» 5 (130) 2020 «System technologies»

DOI 10.34185/1562-9945-5-130-2020-11

УДК 004.9

В.Ю. Каштан, В.В. Гнатушенко

\title{
ВИДАЛЕННЯ ТІНЕЙ НА ЦИФРОВИХ КОСМІЧНИХ ЗНІМКАХ НА ОСНОВІ ВЕЙВЛЕТ-ПЕРЕТВОРЕННЯ
}

Анотація. Розглянуто проблему ідентифікації та компенсації тіней на космічних знімках високого просторового розрізнення. У роботі використано знімки міської території, отримані супутником WorldView-3. Наявність тіней на знімках може привести до втрати корисної інформації і навіть помилок в роботі алгоритмів розпізнавання, виявлення, відстеження $і$ класифікації об'єктів. Запропоновано новий алгоритм автоматичного виявлення та усунення тіней цифрових космічних знімків, що дозволяє відновити освітленість та підвищити якість цих знімків. Для цього використано перехід до кольорової метрики HSV, вейвлет-перетворення та контурну сегментацію. Порівняння кількісних показників, а також візуальні результати показали перевагу використання запропонованого алгоритму. Результати роботи можуть бути використані при подальшому розпізнаванні об'єктів та тематичній обробці космічних знімків.

Ключові слова: космічні знімки, вейвлет-перетворення, сегментація, текстурна характеристика, виявлення тіні, видалення тіні, кольорова метрика HSV.

Постановка проблеми. Космічні знімки високого і надвисокого просторового розрізнення знаходять застосування в різних прикладних областях і дозволяють вирішувати найрізноманітніші завдання. За допомогою таких знімків можна діагностувати стан посівів, оцінювати типи грунтів та навантаження на них, прогнозувати врожаї, виділяти водні об’єкти, виконувати інвентаризацію лісів із визначенням видового та вікового складу, визначати екологічний стан території, тощо [1]. Необхідність вилучення корисної інформації з первинних даних вимагає розробки нових автоматизованих програмних комплексів, здатних обробляти велику кількість інформації [2,3]. Серед безлічі різних задач, які віршуються за допомогою обробки даних дистанційного зондування особливе місце займає задача видалення тіней. Цей клас задач потребує визначен-

(C) Каштан B.Ю., Гнатушенко В.В., 2020 
«Системні технології» 5 (130) 2020 «System technologies»

ня змін на різночасових сценах знімків високого просторового розрізнення за короткий термін. Часто космічні знімки поверхні Землі містять різні шуми, в тому числі і тіні від різних об'єктів (хмар і високих будівель, дерев та ін.). Наявність затінених ділянок та ступінь поглинання чи відбиття світлових променів ускладнює процес розпізнавання і локалізації різних об'єктів, що є одним з найбільш складних і дорогих 3 точки зору витрат часу. Через великі витрати на обробку даних, автоматизація цього процесу набуває актуального значення. Існуючі методи видалення тіней на космічних знімках мають ряд недоліків, основним з яких є поява неоднорідності спектральних характеристик та «роздробленості» об’єктів, що суттєво ускладнює подальшу тематичну обробку даних.

Аналіз останніх досліджень. В даний час для вирішення задачі видалення тіней на космічних знімках розроблено велику кількість методів та присвячено велику кількість робіт. Дана задача залишається однією з фундаментальних проблем аналізу інформації дистанційного зондування Землі. Існуючі методи видалення тіней можна розділити на використання фізичних властивостей світла, алгоритмічні методи та методи калібрування камери супутників. В роботах [4,5] запропоновано ефективний алгоритм видалення тіней RGB зображень, що використовує їх радіометричну постобробку. Це дозволило виділити тіні на супутникових знімках Quickbird. Основним недоліком є складність автоматичного підбору порогу бінаризації зображення. Роботи [4,6,7] присвячені виділенню тіней на мультиспектральних знімках 3 використанням інваріантності кольорового простору RGB. Виявлення тіні здійснюється на основі розкладу зображення на R, G, B компоненти. Потім попіксельно обчислюються матриці тіней $\mathrm{r}_{\mathrm{m}}, \mathrm{g}_{\mathrm{m}}$, $\mathrm{i}$ таким чином зменшується різниця між тіньовою областю та сусідніми освітленими областями. Перевагами даного методу є його швидкість, простота реалізації та ефективність. Але існуючий метод в досить складних сценах тінь не видаляє, а лише послаблює. В роботах [8, 9] запропоновано метод, в якому видалення тіней здійснюється в три етапи: створюється 1D безтіньове зображення 3 постійним освітленням, 2D зображення, яке містить інформацію про колір та 3D безтіньове кольорове зображення. При цьому границі тіні ко- 
«Системні технології» 5 (130) 2020 «System technologies»

ригуються за допомогою процедури зафарбовування. Метод вимагає калібрування, крім того може помилково класифікувати деякі межі об’єктів результуючого зображення як границі тіні. Робота [10] присвячена виділенню тіней з використанням переходу до кольорового простору HSV. Виявлення тіні здійснюється на основі аналізу компонент H i S, зображення сегментується на декілька областей, які мають однакову щільність тіней. Для видалення тіней інтенсивність відповідних пікселів підвищується, а потім здійснюється корекція кольору затінених ділянок вже у колірному просторі RGB. Перевагою цього методу є його швидкість. Але метод добре працює на зображеннях з різкими границями тіні. Алгоритм запропонований у роботі [11] базується на аналізі форми віконних гістограм яскравостей космічних знімків. Алгоритм використовує вікна гістограм еталонного зображення та «спеціального» зображення, інваріантного до освітлення. В результаті порівняння значень яскравості віконних гістограм двох зображень будується нове вікно безтіньового зображення. Метод дає непогані результати для тіней з різкими границями, але потребує послідовності зображень, що містять одну сцену при різних умовах денного світла. Проведені дослідження підтвердили необхідність розробки більш ефективного алгоритму видалення тіней на космічних знімках високого просторового розрізнення з урахуванням спектральних та просторових ознак, апріорних і експертних відомостей.

Метою даної роботи $є$ розробка нового алгоритму автоматичного видалення текстури тіньових областей космічних знімків з врахуванням спектральних та просторових ознак на основі HSV-, вейвлетперетворення та контурної сегментації. У якості вхідних даних використовуються космічні знімки супутника WorldView-3. Для визначення ефективності розробленого алгоритму будуть отримані кількісні оцінки якості видалення тіней багатоспектрального зображення.

Виклад основного матеріалу. На основі проведених досліджень [12,13], в даній роботі пропонується алгоритм видалення тіней космічних знімків 3 використанням контурної сегментації даних [14] на основі побудови вейвлет-базисів $з$ декореляцією первинних 
«Системні технології» 5 (130) 2020 «System technologies»

видових даних. Схема алгоритма представлена на рис.1. Реалізація цього алгоритму наступна:

1. Завантажуємо багатоспектральне зображення $R G B$.

2. Декореляція первинного багатоспектрального зображення у кольорову модель $H S V$ (позначимо $\left.H S V_{R G B}\right)$ :

$$
\left.\begin{array}{c}
H=\left\{\begin{array}{c}
\theta, \text { якщо } B \leq G \\
360^{\circ}-\theta, \text { якщо } B>G
\end{array} ;\right. \\
S=1-\frac{3}{R+G+B} \min (R, G, B) ; \\
\text { де } \theta=\cos ^{-1}\left\{\frac{1}{3}(R+G+B) .\right. \\
\sqrt{(R-G)^{2}+(R-B)(G-B)}
\end{array}\right\} .
$$

Оскільки тінь менш освітлена, ніж нетіньова частина зображення, то їі можливо виявити при розгляді каналів насиченості $(S)$ та яскравості $(V)$, що зберігають інформацію про світлоту. Для більшості зображень значення компоненти $V$ менше в тіньових областях. Тому для виявлення тіней аналізуємо значення параметрів $S$ та $V$ кожного пікселя.

3. Наступним етапом є застосування вейвлет-перетворення. Дане перетворення згладжує зміни яскравості об’єктів, так що локальні контрасти зображення зменшуються, що дозволяє виявити тіні об’єктів. Виконуємо вейвлет-перетворення над компонентами $S_{H S V R G B}$ та $V_{H S V R G B}$. Розклад відповідних компонентів зображення здійснюється до першого рівня декомпозиції $(L)$, так як цього достатньо для виявлення тіней, за оптимального вейвлет-базису з розкладанням на апроксимуючі та деталізуючи коефіцієнти:

$$
\begin{aligned}
& f_{R G B}(r) \rightarrow f_{X Y Z}(r), \\
& W(S)=T c_{X}^{L}(S)+\sum_{l=1}^{L}\left[T d_{X}^{l, 1}(S)\right], \\
& W(V)=T c_{X}^{L}(V)+\sum_{l=1}^{L}\left[T d_{X}^{l, 1}(V)\right],
\end{aligned}
$$

де $T c_{X}^{L}$ i $T d_{X}^{l, 1}$ - апроксимуючі та деталізуючи коефіцієнти рівня $L$. 
«Системні технології» 5 (130) 2020 «System technologies»

4. Апроксимуючі коефіцієнти зображень $W_{S}$ та $W_{V}$ містять позитивні значення вейвлет-перетворення, що асоціюються з яскравістю пікселя; деталізуючі коефіцієнти - значення, які коливаються близько нуля. Пікселі з найбільш високим абсолютним значенням вейвлет-коефіцієнтів $W s(i, j)>W v(i, j)$, позначаються як тіньові, а решта - як нетіньові. Пікселі 3 найбільш низьким абсолютним значенням вейвлет-коефіцієнтів $D(i, j)>T$ можуть бути класифіковані як ті, що належать тіні, а інші - як не тіньові. Далі обчислюємо відносну контрастну різницю та отримуємо тіньову маску:

$$
D(i, j)=\frac{W s(i, j)-W v(i, j)}{W s(i, j)+W v(i, j)}
$$

де $D(i, j)$ являє собою процентну різницю і порівнюється 3 граничним значенням $T$. Якщо різниця більше, ніж $T$, можна зробити висновок, що в еталонному зображенні в місці розташування $(i, j) \in$ тінь. Порівнюючи $W s$ $(i, j)$ зі $W v(i, j)$, можна визначити, в якій із них знаходиться тінь.

5. Отримана на попередньому етапі тіньова маска часто містить велику кількість неправильно класифікованих пікселів, областей тіні, особливо ті, які розташовані поблизу тіньової границі та належать одному і тому ж типу об’єктів. Ці області мають різкі границі та інтенсивність, що містить мало інформації про текстуру поверхні та ускладнює її видалення зі збереженням природного вигляду текстури. Тому наступним етапом $\epsilon$ застосування контурної сегментації до зображення $D(i, j)$, запропонованої у роботі [14], що дозволяє визначити просторові та спектральні особливості об’єкта одного і того ж типу з обох сторін та точно визначити границі тіньових областей.

6. Наступним етапом є видалення тіні з зображення. Для цього розраховуємо порогове значення області бінарної маски компоненти яскравості:

$$
M_{\text {shad }}=\left\{\begin{array}{c}
1, \text { при } W v \geq D(i, j)_{W v} \wedge W s \geq D(i, j)_{W s} . \\
0, \text { в інших випадках }
\end{array} .\right.
$$

7. Виконаємо зворотне вейвлет-перетворення та перехід до кольорової метрики RGB: 
«Системні технології» 5 (130) 2020 «System technologies»

$$
\begin{aligned}
& f_{\bar{X} Y Z}(r)=A p p_{X}^{L}(r)+\operatorname{Det}_{\bar{X}}(r), \\
& f_{\bar{X} Y Z}(r)=f_{\overline{R G B}}(r) .
\end{aligned}
$$

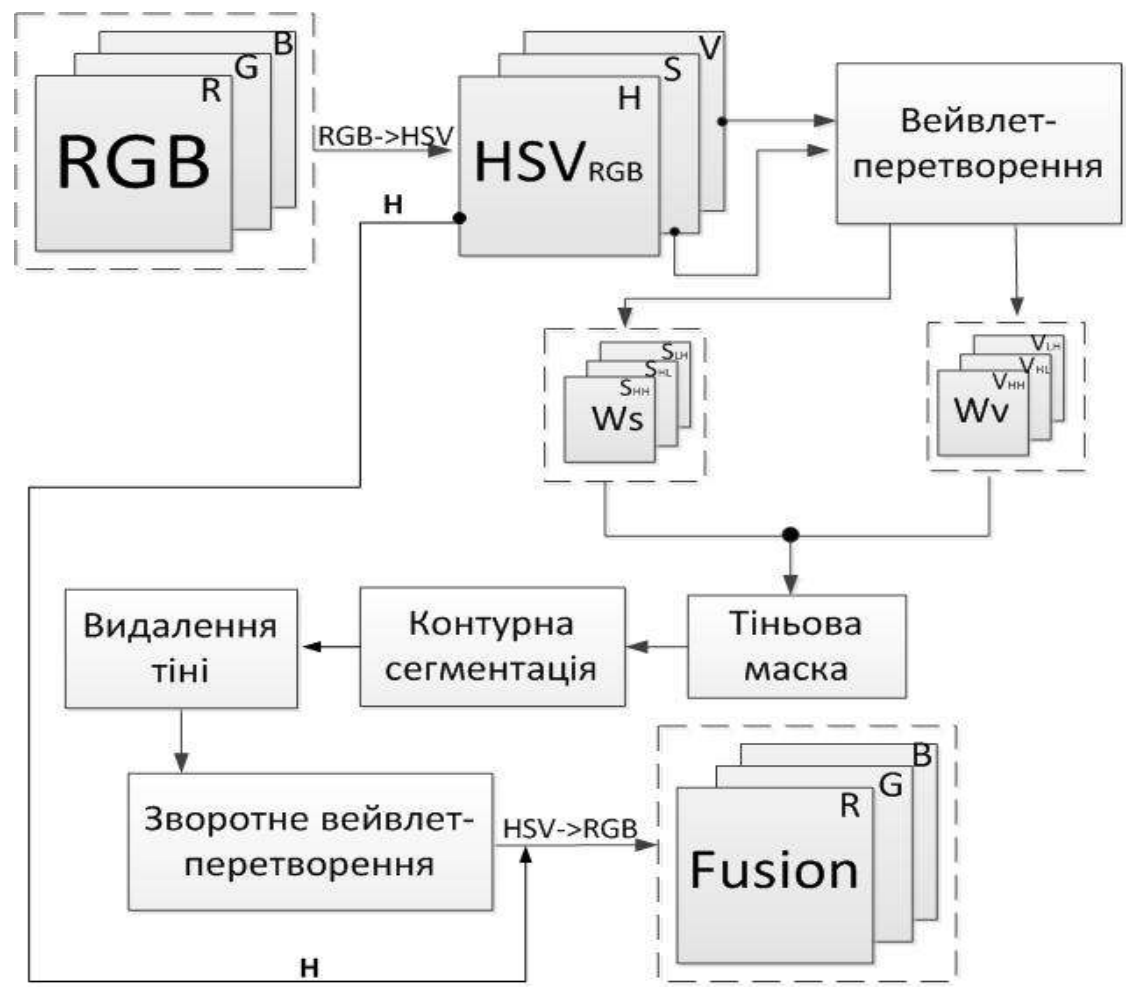

Рисунок 1 - Схема алгоритму видалення тіні

Запропонований алгоритм був протестований на космічних знімкаx Worldview-3 з просторовим розрізненням: 1,24 м - в багатоканальному режимі, 3,7 - в інфрачервоному діапазоні. На рис. 2 представлені зображення: до обробки - фрагмент багатоканального зображення 3 вибором у якості окремих R-, G-, B-компонент, що містить об'єкти місцевості (рис 2а), тіньової бінарної маски (рис.2б), контурної сегментації (рис. 2в) та після обробки запропонованим у роботі алгоритмом (рис.2г). Візуальний аналіз одержаних результатів дозволяє видалити текстуру тіньової області на супутниковому зображенні, що є близьким до еталонного зображення.

Крім візуальної якості обробки зображень була проаналізована точність виділення тіней космічних знімків:

1. Точність тіньових областей $p_{s}[15]$ : 
«Системні технології» 5 (130) 2020 «System technologies»

$$
p_{s}=\frac{T P}{T P+F P}
$$

де $T P$ - кількість пікселів еталонного зображення, $F P$ - кількість не тіньових пікселів, що належать тіні.

2. Точність нетіньових областей $p_{n}$ :

$$
p_{n}=\frac{T N}{T N+F N},
$$

де - FN - кількість тіньових пікселів, що належать тіні, $T N$ - загальна кількість не тіньових пікселів, що дорівнює:

$$
T P+T N+F P+F N
$$

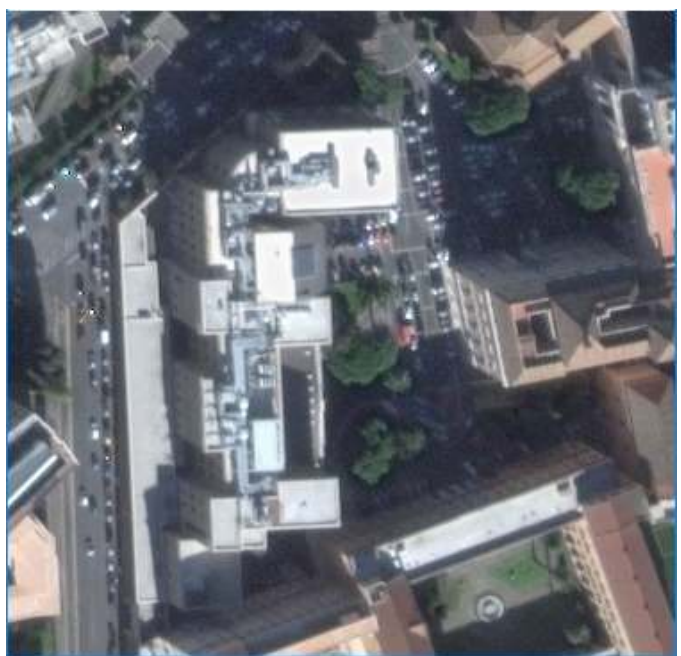

a) первинне

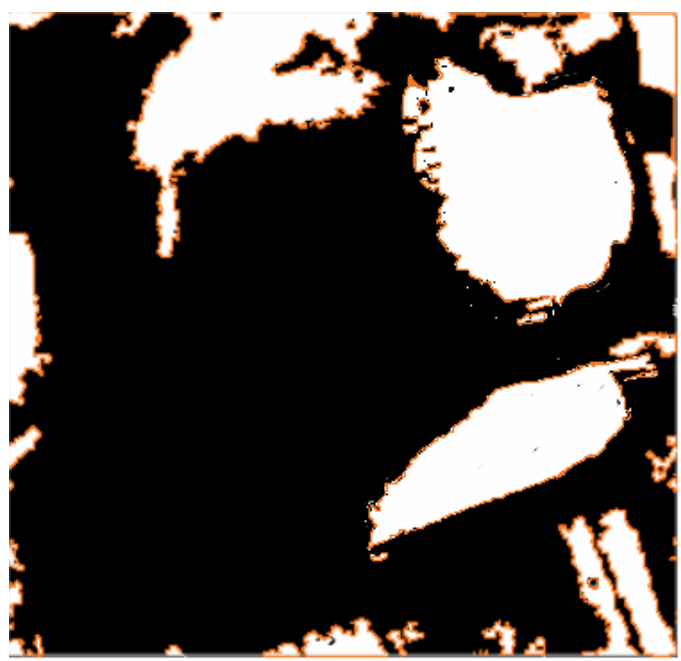

в) контурна сегментація

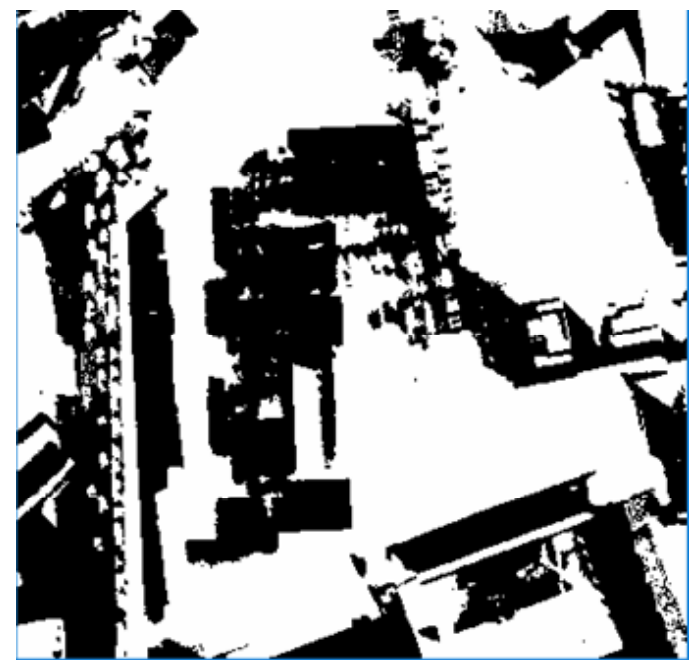

б) тіньова маска

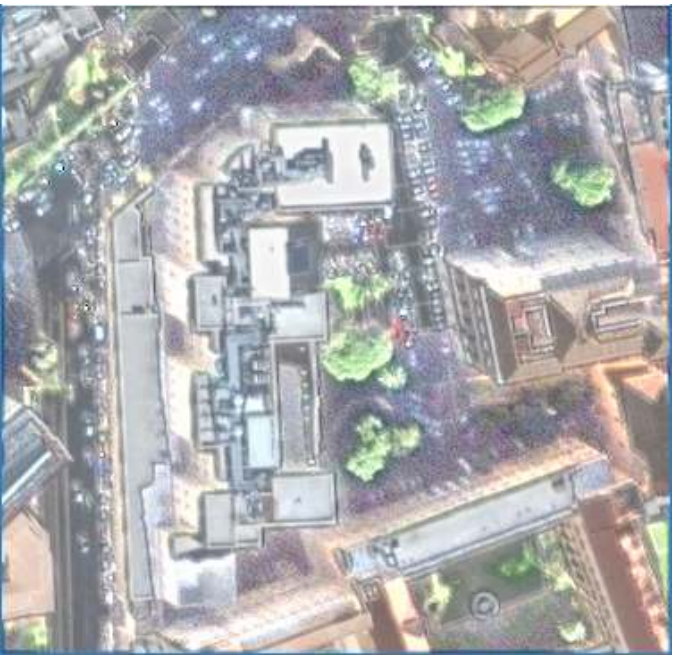

г) після обробки

Рисунок 2 - Фрагменти зображень 
«Системні технології» 5 (130) 2020 «System technologies»

У таблиці 1 представлені експериментальні результати оцінки точності виділення тіней, отриманих окремо відомими кольоровими метриками (HSV, HSI, YIQ, HCV) і запропонованим у роботі алгоритмом. Показано, що запропонований алгоритм дозволяє краще виділяти області тіней у порівняні з існуючими кольоровими метриками. При порівнянні двох зображень пропонується також використовувати пікове відношення сигнал-шум (PSNR), яке означає співвідношення між максимумом можливого значення сигналу і потужністю шуму, що спотворює значення сигналу:

$$
P S N R=20 \log _{10}\left(\frac{L^{2}}{\frac{1}{M N} \sum_{x=1}^{M} \sum_{y=1}^{N}\left(I_{r}(x, y)-I_{f}(x, y)\right)^{2}}\right),
$$

де $x_{i}, y_{i}$ - початкові координати, $x_{r}, y_{r}$ - кінцеві координати.

Таблиця 1

Результати оцінки точності виділення тіней за допомогою різних критеріїв

\begin{tabular}{|c|c|c|}
\hline $\begin{array}{c}\text { Кольорові } \\
\text { метрики }\end{array}$ & $\begin{array}{c}\text { Точність тіньових об- } \\
\text { ластей, } \mathrm{p}_{\mathrm{s}}(\%)\end{array}$ & $\begin{array}{c}\text { Точність не тіньових } \\
\text { областей, } \mathrm{p}_{\mathrm{n}}(\%)\end{array}$ \\
\hline HSV & 79,2 & 88,1 \\
\hline HSI & 39,5 & 88,5 \\
\hline YIQ & 88,1 & 92,4 \\
\hline HCV & 80,8 & 70,3 \\
\hline $\begin{array}{c}\text { Запропонований } \\
\text { (Fusion) алгоритм }\end{array}$ & 95,6 & 94,7 \\
\hline
\end{tabular}

У таблиці 2 наведено розраховані коефіцієнти PSNR для первинного та синтезованого зображень. Аналіз отриманих результатів дозволяє визначити, що візуальна якість еталонного зображення нижча ніж при використанні запропонованого алгоритму, що впливає на якість розпізнавання об’єктів та підвищують якість первинних космічних знімків на $10-12 \%$. 
«Системні технології» 5 (130) 2020 «System technologies»

Таблиця 2

Результати коефіцієнта PSNR

\begin{tabular}{|l|c|}
\hline \multicolumn{1}{|c|}{ Зображення } & PSNR \\
\hline Еталонне & 17,1391 \\
\hline Після видалення тіней & 22,1391 \\
\hline
\end{tabular}

Для оцінки швидкості роботи існуючих методів видалення тіней (AP, K-means) та запропонованого в роботі алгоритму було розраховано середній час їх роботи для тестового космічного знімку. Оцінка швидкості роботи методів виконувалась на персональному комп’ютері з наступними параметрами: CPU Intel Core 2 Quad Q6600, 2.4 GHz, 8Гб оперативної пам'яті, операційна система Windows 10. Результати роботи методів видалення тіней наведені в таблиці 3.

Таблиця 3

Результати дослідження швидкості обробки методів видалення тіней

\begin{tabular}{|c|c|}
\hline \multirow{2}{*}{ Методи } & Швидкість обробки даних в сек. \\
\cline { 2 - 2 } & Космічний знімок (25228770 байт) \\
\hline АР & 120,11 \\
\hline К-mеans & 45,13 \\
\hline Запропонований метод & 1,50 \\
\hline
\end{tabular}

Висновки. У роботі вирішено актуальну задачу автоматичного виявлення та видалення тіней на цифрових космічних знімках. Наукова новизна та практична цінність роботи полягає у розробці нового методу видалення тіней космічних знімках WorldView-2 на сонові HSV-, вейвлет-перетворення та контурної сегментації, що дозволяє скоротити час на обробку даних та підвищити точність подальшого розпізнавання об'єктів на зображеннях. Це досягається, зокрема, за рахунок згладжена зміни яскравості об’єктів , так що локальні контрасти зображення зменшуються, що дозволяє виявити області тіней об'єктів та виділити границі тіньових об'єктів зі збереженням природного вигляду текстури поверхні на основі комплексного використання вейвлет-перетворення та контурної сегментації. Тестування показали, що запропонований алго96 
«Системні технології» 5 (130) 2020 «System technologies»

ритм підвищує достовірність видалення тіней цифрових зображень, при цьому враховує тіньові особливості на границях зображення, поданого до аналізу, і може використовуватися для попередньої обробки космічних знімків.

\section{ЛІТЕРАТУРА / ЛИТЕРАТУРА}

1. Schowengerdt R. (2007), Remote sensing: models and methods for image processing, New York: Academic Press. P.560.

2. Pansharpening technology of high resolution multispectral and panchromatic satellite images / V. V. Hnatushenko, Vik. V. Hnatushenko, O. O. Kavats, V. Yu. Shevchenko // Scientific Bulletin of National Mining University. - 2015. - № 4. - P. 91-98

3. Hnatushenko V.V., Hnatushenko Vik.V., Mozgovyi D.K., Vasyliev, V.V. "Satellite technology of the forest fires effects monitoring”. Scientific Bulletin of National Mining University, 2016. Issue 1 (151), pp. 70-76.

4. Marchant J.A., Onyango C.M. Shadow invariant classification for scenes illuminated by daylight // Journal Optical Society of America A. - 2000. - Vol. 17. - № 12. - P.1952-1961.

5. Renno, J.-P.R. Evaluation of shadow classification techniques for object detection and tracking / J.-P.R. Renno, J. Orwell, G.A. Jones // International Conference on Image Processing. - Singapore, 2004. - Vol. 1. - P.143-146.

6. Chen, B. Shadow Detection Based on RGB Color Model // B. Chen, D. Chen / Intelligent Computing in Signal Processing and Pattern Recognition. Lecture Notes in Control and Information Sciences. - 2006. - Vol. 345. - P. 10681074.

7. Finlayson G. D. On the Removal of Shadows from Images / G. D. Finlayson, S. D. Hordley, C. Lu, M. S. Drew // IEEE Transactions on Pattern Analysis and Machine Intelligence. - 2006. - Vol. 28, № 1. - P. 59-68.

8. Giles, P. Remote sensing and cast shadows in mountainous terrain / P. Giles // Photogrammetric Engineering \& Remote Sensing. - 2001. - Vol. 67 (7). - P. 833-839.

9. Rau, J.-Y. True orthophoto generation of built-up areas using multi-view images / J.-Y. Rau, N.-Y. Chen, L.-C. Chen // Photogrammetric Engineering \& Remote Sensing. - 2002. - Vol. 68 (6). - P. 581-588.

10. R.Cucchiara, C.Grana, M. Piccardi, A. Prati, Detecting moving objects, ghosts, and shadows in video streams//IEEE Transactions on Pattern Analysis and Machine Intelligence, vol. 25, no. 10, 2003, pp. 1337-1342. 
«Системні технології» 5 (130) 2020 «System technologies»

11. Dare, P.M. Shadow analysis in high-resolution satellite imagery of urban areas / P.M. Dare // Photogrammetric Engineering and Remote Sensing. 2005. - Vol. 71. - P. 169-177.

12. Kahtan V.Yu. Satellite Imagery Features for the Image Similarity Estimation [Electronic recourse] / Y. I. Shedlovska, V. V. Hnatushenko, V. Yu. Kashtan // International Young Scientists Forum on Applied Physics 2017, October, 16 - 20, Lviv, Ukraine : Proceedings. -Lviv, 2017. - p. 359-362.

13. Kahtan V.Yu. Processing technology of multispectral remote sensing images [Electronic recourse] / V.Yu. Kahtan, V. V. Hnatushenko, Y. I. Shedlovska // International Young Scientists Forum on Applied Physics. 2017. October, 16 - 20, Lviv, Ukraine: Proceedings. Lviv, 2017. - p. 355-358.

14. Каштан В.Ю. Контурна сегментація цифрових супутникових знімків 3 виділенням особливих точок на основі вейвлет-перетворення / В.Ю. Каштан, В.В. Гнатушенко // Системні технології. Регіональний міжвузівський збірник наукових праць. - Випуск 1 (120): зб. наук. праць. - Дніпро, 2019. - с. 3-11.

15. Eli Arbel and Hagit Hel-Or. "Shadow Removal Using Intensity Surfaces and Texture Anchor Points". IEEE. transactions on pattern analysis and machine intelligence, vol. 33, no. 6, June 2011.

\section{REFERENCES}

1. Schowengerdt R. (2007), Remote sensing: models and methods for image processing, New York: Academic Press. P.560.

2. Pansharpening technology of high resolution multispectral and panchromatic satellite images / V. V. Hnatushenko, Vik. V. Hnatushenko, O. O. Kavats, V. Yu. Shevchenko // Scientific Bulletin of National Mining University. - 2015. - № 4. - P. 91-98

3. Hnatushenko V.V., Hnatushenko Vik.V., Mozgovyi D.K., Vasyliev, V.V. "Satellite technology of the forest fires effects monitoring". Scientific Bulletin of National Mining University, 2016. Issue 1 (151), pp. 70-76.

4. Marchant J.A., Onyango C.M. Shadow invariant classification for scenes illuminated by daylight // Journal Optical Society of America A. - 2000. - Vol. 17. - № 12. - P.1952-1961.

5. Renno, J.-P.R. Evaluation of shadow classification techniques for object detection and tracking / J.-P.R. Renno, J. Orwell, G.A. Jones // International Conference on Image Processing. - Singapore, 2004. - Vol. 1. - P.143-146. 


\section{«Системні технологіï» 5 (130) 2020 «System technologies»}

6. Chen, B. Shadow Detection Based on RGB Color Model // B. Chen, D. Chen / Intelligent Computing in Signal Processing and Pattern Recognition. Lecture Notes in Control and Information Sciences. - 2006. - Vol. 345. - P. 10681074.

7. Finlayson G. D. On the Removal of Shadows from Images / G. D. Finlayson, S. D. Hordley, C. Lu, M. S. Drew // IEEE Transactions on Pattern Analysis and Machine Intelligence. - 2006. - Vol. 28, № 1. - P. 59-68.

8. Giles, P. Remote sensing and cast shadows in mountainous terrain / P. Giles // Photogrammetric Engineering \& Remote Sensing. - 2001. - Vol. 67 (7). - P. 833-839.

9. Rau, J.-Y. True orthophoto generation of built-up areas using multi-view images / J.-Y. Rau, N.-Y. Chen, L.-C. Chen // Photogrammetric Engineering \& Remote Sensing. - 2002. - Vol. 68 (6). - P. 581-588.

10. R.Cucchiara, C.Grana, M. Piccardi, A. Prati, Detecting moving objects, ghosts, and shadows in video streams//IEEE Transactions on Pattern Analysis and Machine Intelligence, vol. 25, no. 10, 2003, pp. 1337-1342.

11. Dare, P.M. Shadow analysis in high-resolution satellite imagery of urban areas / P.M. Dare // Photogrammetric Engineering and Remote Sensing. 2005. - Vol. 71. - P. 169-177.

12. Kahtan V.Yu. Satellite Imagery Features for the Image Similarity Estimation [Electronic recourse] / Y. I. Shedlovska, V. V. Hnatushenko, V. Yu. Kashtan // International Young Scientists Forum on Applied Physics 2017, October, 16 - 20, Lviv, Ukraine : Proceedings. -Lviv, 2017. - p. 359-362.

13. Kahtan V.Yu. Processing technology of multispectral remote sensing images [Electronic recourse] / V.Yu. Kahtan, V. V. Hnatushenko, Y. I. Shedlovska // International Young Scientists Forum on Applied Physics. 2017. October, 16 - 20, Lviv, Ukraine: Proceedings. Lviv, 2017. - p. 355-358.

14. Kashtan V.Iu. Konturna sehmentatsiia tsyfrovykh suputnykovykh znimkiv z vydilenniam osoblyvykh tochok na osnovi veivlet-peretvorennia / V.Iu. Kashtan, V.V. Hnatushenko // Systemni tekhnolohii. Rehionalnyi mizhvuzivskyi zbirnyk naukovykh prats. - Vypusk 1 (120): zb. nauk. prats. Dnipro, 2019. - s. 3-11.

15. Eli Arbel and Hagit Hel-Or. "Shadow Removal Using Intensity Surfaces and Texture Anchor Points". IEEE. transactions on pattern analysis and machine intelligence, vol. 33, no. 6, June 2011. 


\section{«Системні технології» 5 (130) 2020 «System technologies»}

\section{удаление теней на цифровых космических снимках на основе вейвлет-преобразования}

В работе предложен новый метод автоматического удаления теней на цифровых космических снимках с использованием их иветных и текстурных характеристик на основе вейвлет-преобразования. Предложенный метод был протестирован на спутниковых изображениях. Полученные количественные показатели для предлагаемого метода, а также визуальные результаты показали преимущество использования предложенного метода. Результаты работы могут быть использованы при дальнейшем распознавании объектов и тематической обработке спутниковых снимков.

Shadow removal on digital satellite images using wavelet transforms

Shadow detection and removal in real scene images is always a challenging but yet intriguing problem. Shadows cause hindrance to correct feature extraction of image features like buildings, towers etc. in urban areas it may also cause false color tone and shape distortion of objects, which degrades the quality of images. Hence, it is important to segment shadow regions and restore their information for image interpretation. Shadows are generated by a local and relative absence of light. Shadows are, first of all, a local decrease in the amount of light that reaches a surface. Secondly, they are a local change in the amount of light rejected by a surface toward the observer. Most shadow detection and segmentation methods are based on image analysis. This paper presents a novel algoritm for automatic shadow detection and removing shadows using HSV color model, contour segmentation and wavelet transform based on a threshold determined by wavelet coefficients in complex urban color remote sensing images for solving problems caused by shadows. In the proposed algoritm shadows are detected using $S$ and $V$ components which is invariant to shadow i.e., it conveys the spectral and color characteristics of image features, regardless of variations in scene illumination condition and means of wavelet coefficients. The multi-resolution property of the wavelet transform leads into four different bands without the loss of spatial information. Once the shadows are detected they are classified and a non shadow area around each shadow termed as buffer area is estimated using contour segmentation. Experiments show that the new algoritm can accurately detect shadows from urban high-resolution remote sensing images and can effectively restore shadows with a rate of over $85 \%$. The proposed algoritm can be used for further object recognition and thematic processing of scanner images.

Каштан Віта Юріївна - к.т.н, доцент кафедри комп’ютерних наук та інформаційних технологій Дніпровського національного університету імені Олеся Гончара (м. Дніпро).

Гнатушенко Володимир Володимирович - д.т.н., професор, завідувач кафедри інформаційних систем та технологій Національного технічного університету «Дніпровська політехніка» (м. Дніпро).

Каштан Вита Юрьевна - к.т.н., доцент кафедры компьютерных наук и информационных технологий Днепровского национального университета имени Олеся Гончара (г. Днепр). 
«Системні технології» 5 (130) 2020 «System technologies»

Гнатушенко Владимир Владимирович - д.т.н., профессор, заведующий кафедры информационных систем и технологий национального технического университета «Днепровская политехника» (г. Днепр).

Kashtan Vita - Ph.D. in technical science, assistant professor of department of computer science and information technologies, Oles Honchar Dnipro National University, Dnipro, Ukraine.

Hnatushenko Volodymyr - doctor of technical science, professor, head of department of information systems and technologies, Dnipro University of Technology, Dnipro, Ukraine. 